\title{
The Triad of Transnationalism, Legal Recognition, and Local Community: Shaping Political Space for the Burmese Refugees in Japan
}

\author{
SUSAN BANKI
}

\begin{abstract}
Refugee participation in transnational acts - from advocating for regime change in home countries to strengthening modes of safe passage for friends and family to host countries - is only as effective as the ability of refugees to organize, collaborate with one another, and develop strong communication links between communities in the home and host countries. While many assume that legal status improves the ability of refugees to engage in political transformation, research on the Burmese refugees living in Japan reveals that the application and provision of legal status can have the opposite effect, weakening fragile community structures, stemming advocacy efforts, and discouraging communication between divided political and ethnic groups. I argue that transnational acts form a three-way relationship with legal recognition and local community, and that, because of conflictual relationships among local refugee communities, refugees from Burma with higher degrees of legal recognition in Japan do not necessarily expand transnational space.
\end{abstract}

\section{Résumé}

La participation des réfugiés aux lois transnationales depuis leur plaidoyer en faveur d'un changement de régime dans les pays d'origine au renforcement des modes de passage sécuritaire pour les amis et la famille vers les pays hôtes - est aussi efficace que leur capacité à organiser, à collaborer entre eux et à établir des liens étroits de communication entre les pays d'origine et d'accueil. Bien qu'il soit admis que la situation juridique améliore la capacité des réfugiés à envisager une transformation politique, des recherches menées auprès des réfugiés birmans qui résident au Japon révèlent que l'application et la disposition de la situation juridique peut avoir l'effet inverse et fragiliser les structures communautaires, interrompre les tentatives de plaidoyer et décourager la communication entre les groupes politiques et ethniques déjà divisés. L'article défend la thèse que les lois transnationales forment une relation à trois avec la reconnaissance juridique et la communauté locale et que, à cause de relations conflictuelles parmi les communautés locales de réfugiés, les réfugiés de Birmanie dotés d'un fort taux de reconnaissance juridique au Japon n'élargissent pas nécessairement l'espace transnational.

$\mathrm{R}$ efugees who have fled protracted conflict find various means of advocating for change in their countries of origin. They assemble to discuss the political and economic situation in their region of origin, they share news and dismiss rumours through social networks, they distribute information through media outlets and nongovernmental organizations (NGOs), and they demonstrate and organize protests in order to call attention to the conditions in their home country.

These acts of communication and coordination not only cross borders, but in generating new strategies and resources to mobilize internal and exiled populations, they transcend them. Such political actions take place "over and beyond" the borders of home and host countries, and thus lie in the transnational realm. ${ }^{1}$

Refugees have varying degrees of legal recognition in their host country, ranging from official "refugee" status to temporary status to special residence permits to entirely illegal. Regardless of the specific terminology of each country, it is believed that the possession of legal status expands 
transnational political space. ${ }^{2}$ That is, there is an underlying assumption that migrants and refugees with legal recognition are better able, and more likely, to engage in political advocacy than those who are illegal.

In studying the particularities of the Burmese refugee community in Japan, this paper challenges that unidirectional assumption and complicates the relationship between legal status and transnationalism. Rather, transnational acts are part of a three-way relationship including legal recognition and local community. The development and maintenance of local refugee communities in Japan influence and are influenced by both legal status and transnational political acts, often in surprising ways. Despite the fact that legal recognition is thought to provide greater freedom of expression and movement and thus more opportunities to engage in advocacy efforts, in the Burmese refugee community in Japan, conflict arises from the application and provision of legal status, and transnational space is often diminished as a result.

I begin the paper by considering the transnational components and nature of refugee advocacy movements. Next, drawing from the literatures on transnationalism and diaspora, I describe the elements of the three-way relationship between transnational acts, legal status, and local community. Two months of field research in Japan - documentation, direct observation, and interviews - illuminate the remaining sections. First, I review the legal and factual circumstances surrounding the Burmese refugees in Japan. Second, I map the Burmese refugee community by ethnicity and political groups, comparing those with and without legal status. I conclude by specifying the connections between transnationalism, legal recognition, and local community.

\section{Transnational Actors}

Transnationalism is neither the unique domain of individuals nor of networks created by individuals. The ability of corporations, NGOs, liberation movements, cultural groups, and other non-state actors to partake in transnational acts has been noted by many. ${ }^{3}$ In the migration literature, however, transnational action has moved to the forefront, as authors appropriately focus on the ways in which migrants and refugees are able to use transnational space in order to promote their agendas or agitate against undesirable policies.

Particularly, there is a value in understanding how refugees engage in transnational acts, and how they are able to define and refine their identities beyond the restrictive boundaries of a hostile home country and an (often) unwelcoming host country. Political action is particularly meaningful for refugees who have presumably fled from a government of persecution and discrimination. This paper, then, focuses on the specifics of refugee transnationalism in its political form. ${ }^{4}$

\section{Transnational Action (and Emotion)}

The topic of transnationalism has been bandied around just long enough that it is perhaps no longer accurate to call it a vogue topic (although it is certainly not yet retro). The field's numerous commentators draw from, among other disciplines, anthropology, cultural studies, political science, sociology, and migration. ${ }^{5}$ Nevertheless, the discourse on transnationalism continues to play a salient role in the literature, reflecting its substantial significance in reality.

Transnationalism in all its forms - from developing transborder social networks to strengthening modes of safe passage to host countries to sending remittances home - is indeed a relevant phenomenon. Technological advances have facilitated the transfer of information and money, and superior methods of transportation have eased the ability of migrants and refugees to move physically from one country to another. ${ }^{6}$

Specifically, transnational political action utilizes these exchanges in order to effect political change in the home country, and transnational space is the arena in which these efforts are made. ${ }^{7}$ Adamson lists three ways political entrepreneurs advocate for changes at home: (1) using exiled voices to challenge the discourse of the home country; (2) raising international awareness through local NGOs and state actors; and (3) sending resources to local actors in the home country. ${ }^{8}$

Van Hear has identified "movements or exchanges of people, money, and information" as the building blocks of transnational action. ${ }^{9}$ However, while individuals hope to accomplish concrete political action, the nature of their exchanges need not be concrete; Van Hear's three fundamental items can be supplemented by less tangible, but equally important, elements. In addition to the movement of people, money, and information, transnational space allows for the exchange of questions, ideas, strategies, and decisions. This differentiation is necessary because information is traded; ideas are created. Transnational ties, true to their meaning, transcend a simple international exchange of "things" in order to produce knowledge, awareness, and a sense of identity. Likewise, ignorance, indifference, and alienation can occupy transnational space as well.

As the examination of community and its relationship to transnationalism will show further on, sentiment and sensation also move through transnational lines: trust (and distrust), conviction (and doubt), and hope (and despair). Because transnationalism is intricately linked with the ability to establish community networks between those "at home" 
and those abroad, the positive and negative emotions that accompany such relationships are a critical, although, I argue, underexamined aspect of transnational ties. ${ }^{10}$

Indeed, ignorance, indifference, alienation, distrust, doubt, and despair are as likely to exist as elements of transnational space as are their positive counterparts, and this observation highlights what several authors have noted. Transnational forces are not always positive. Migrants may be motivated to participate in transnational political networks for purely nationalistic purposes or purely egotistical ones. Prestige and status may drive individuals to transnationalism, as can social pressure, family influence, and guilt. ${ }^{11}$

Finally, migrants and refugees are capable of using their cross-continental connections not only to foster peaceful solutions but to foment violent revolution. ${ }^{12}$ In studying this question, academics as well as policy makers are drawn to ask: "Can (or should) policies be devised which enhance the positive outcomes of transnational networks, while discouraging transnational activities which fuel or sustain conflicts?"13 If such policies are possible at all, a better understanding of the role of legal status in shaping transnational space is necessary.

\section{Legal Status in the Host Country}

The literature on refugee law is too vast and digressive to discuss here. Germane to this examination, however, are two points: 1) legal status describes only a refugee's legal label and cannot be considered an accurate picture of what he actually is or is not; and 2) legal status has a complicated, multi-faceted relationship with transnational space.

\section{The Refugee Label}

It should be clear that the actual number of refugees in the world - that is, those who have fled their home countries in need of protection elsewhere - far exceeds those with official "refugee" status. The Office of the United Nations High Commissioner for Refugees (UNHCR), driven by the nation-states which support it and host refugees, has no choice but to limit the number of individuals on whom it bestows refugee status. Scarce resources require this. ${ }^{14}$

Host countries construct the same hazy divisions. With limited budgets, few countries are willing to provide refugee legal status to all those who arrive at their borders, and whether accurate or just or neither, restrictions are put into place to allow for identifying and selecting "refugees" out of a larger group. Many host countries shy away from the term "refugee" altogether and employ different categories to determine the treatment of those who cross their borders. This process and the political and domestic factors that shape immigration/refugee quotas yield uneven results. "Official" refugee status as deemed by UNHCR or legal allowances provided by the host country is, at best, a mediocre indicator of whether or not an individual merits the "refugee" label.

The determination of legal status highlights the critical issue of the "migration-asylum nexus," which points to the ambiguity in distinguishing between those who cross borders for economic (migration) or political (asylum) reasons. Many host countries, increasingly unwilling to offer asylum to refugees, instead prefer to identify them as temporary migrant workers. If, over time, refugees understand that their chances to remain in the host country will improve if they claim to be migrant workers, the alarming result is that they will cease applying for asylum. While their status as migrant workers ensures them short-term residence in host countries, it avoids the issue of protection. Unlike migrant labourers, refugees have no foreign body to represent them. ${ }^{15}$

\section{Legal Status and Transnationalism}

It some ways, the positive relationship between legal status and transnational space seems clear and evident. Many scholars have argued that legal status paves the way for transnational space. ${ }^{16}$ With greater freedoms in the host country afforded by legal recognition, refugees can engage in a host of transnational political acts, such as demonstrating without fear of arrest. ${ }^{17}$ Transnational space is also facilitated by place. That is, those who have a place to meet and do not fear assembling to partake in political discussion are better able to further transnational political goals. ${ }^{18}$

However, perceptions about the need for evidence to prove asylum (or other forms of legal status) have embroiled questions of legal status and transnationalism. In explicating asylum policy in the United Kingdom, Shah underlines the fact that political agitation is often used to try to establish asylum claims, while these same transnational political acts can reduce the chances of receiving asylum. ${ }^{19}$ This critical point reveals that the relationship between legal status and political advocacy is not solely positive, and it does not move in only one direction. The complexity of this relationship will be explored further on, particularly as it pertains to the Burmese refugees in Japan.

\section{Community Networks vs. Local Communities}

Networks that link geographically distant communities play a crucial role in maintaining and shaping transnational space. These community networks are an integral mechanism in the facilitation of transnational action. For example, community networks generate information about the host country, circulate it throughout the network's members, and communicate it to potential newcomers. ${ }^{20}$ Networks provide the "organizational infrastructure" to convey migrants and refu- 
gees to host countries, often through clandestine channels. ${ }^{21}$ Finally, community networks between populations in the home and host countries allow for the coordination of advocacy on specific issues and the distribution of relevant and timely news concerning the host government in power.

While community networks are an inherent element of transnational action, local communities play a different role, and the distinction ought to be made clear. By "local communities," I refer to the population in the host country with whom the refugee surrounds himself, and the networks she employs for the purpose of domestic and local concerns. A refugee's local community might include family, friends, employers, and religious compatriots. While local communities may be transnational, they need not be. Perhaps it is axiomatic to assert that local communities with greater transnational connections are more likely to engage in transnational acts, but this point is precisely the basis for the third leg of the triad: the composition and quality of a refugee's local community is an important and overlooked factor in the shaping of transnational political space.

For refugees and other migrant groups, local community is often linked to ethnic identity. Linguistic and cultural similarities with home populations facilitate trust and communication among individuals who feel alienated in the host country. Refugees, often members of minority groups accustomed to relying on one another in the country from which they have fled, continue to cluster together. Naturally, many countries host refugees of more than one ethnicity, and as noted by Ambroso, this transnational identity is not always inclusive. ${ }^{22}$ Exiled communities often vie for the same transnational space in the form of resources, legal aid, media attention, and prestige, and divisions between refugees from different local communities frequently fall along ethnic lines.

The preceding review indicates that the relationships between political transnationalism, legal recognition, local communities, and ethnic identity have not been ignored by any means. However, where this paper hopes to make an original contribution is in placing these relationships within the context of one another. As the following section will show, Japan's Burmese refugee population reveals the ways in which these elements interconnect and influence one another, often in iterative phases.

For the same reasons that this study might be considered valuable and original, it may not be generalizable. First, whether they fled from the rural Arakan state or the urban capital Rangoon, the Burmese refugees in Japan live in the most urban of all resettlement situations. Unlike many of their compatriots who crossed borders into Thailand or Bangladesh to live in rural areas or refugee camps, virtually none of the Burmese in Japan are living outside of the cities. Urban settings have been noted to encourage refugees to depend less on outside forces than rural or camp settings. ${ }^{23}$ In Japan, the fact that Burmese refugees face relatively similar work opportunities and obstacles, similar types of housing, and similar initial access to health and education upon arrival makes the presence (or absence) of local communities that much more influential.

Second, Japan's Burmese refugees are plainly situated in the intermediate term, the nebulous and lengthy period between the post-emergency phase and the resolution of the conflict. ${ }^{24}$ Burmese refugees are engaged in transnational political action in order to, and with the intention to, return to Burma when the conflict subsides. Kurdish and Tamil refugee communities are two other examples of refugee situations where the conflict is ongoing, and, as with all refugees who remain the intermediate term, their sense of security is less stable and more temporary than that of refugees who have found a durable solution. Furthermore, because the conflict is ongoing, it is difficult to measure the effectiveness of advocacy efforts in the short term.

Third, Japan's tiny and relatively new Burmese refugee population does not have the force of a large-scale refugee movement. Its small size has made it somewhat facile to study, but it does not possess what we might call "networks of scale." That is, as more refugees populate a host community for longer periods of time, they gain access to aid, legal status, and other resources. Increasingly, they have the ability to help other refugees and mobilize for demonstrations. Japan's Burmese refugee population is yet too small and new for significant impact. Neither do generational issues present themselves at this time. There are only a handful of Burmese refugee children past elementary school age currently in Japan.

However, as the community grows in numbers and duration of time, refugees will integrate linguistically and economically. This fourth and final point is critical: the Burmese refugee population in Japan is very much in transition. Unless there are drastic changes in Burma or in Japanese immigration policy in the next ten years, the refugee population will not only be better integrated and larger, but will have a significant second generation of children. It is very likely that the composition of those with and without legal status will change as well, although the direction of this change is more difficult to predict, given Japan's ever-changing but consistently restrictive immigration policies.

\section{The Burmese Refugees in Japan}

Notwithstanding generous per-capita donations to UNHCR, refugee status is not easily granted in Japan. ${ }^{25}$ Critics site Japan's high degree of ethnic homogeneity and isolation as 
reasons for its restrictive refugee policies. ${ }^{26}$ Others note the lack of a historical legal framework for conceptualizing the notion of a "refugee" altogether. ${ }^{27}$ In recent years, Japan's efforts to become more involved in the international foreign policy arena have led to some ad hoc attempts to accept more foreigners and refugees into the country on a temporary basis, but legal status for refugees continues to be problematic. $^{28}$ Since 1975, a small number of Indochinese refugees (approximately ten thousand) have resettled in Japan. As part of a quota agreement, most were permitted to remain in or enter the country on a temporary basis. Recently, some have secured permanent residence, but approximately half possess only temporary protection in the form of long-term resident status, which must be renewed every one to three years. Few, if any, have official refugee status, which implies a temporariness which belies the circumstances. ${ }^{29}$ The lack of consistent durable protection proffered by the Ministry of Justice (MoJ) demonstrates that refugee policy has been a low priority for the Japanese government.

Because this paper compares those Burmese in Japan who possess legal status with those who do not, it is clear that not all of those who have fled Burma have received official refugee status in Japan. Thus, the term "refugee" is used loosely here. Because the Japanese government has recognized very few Burmese (and few asylum seekers of any nationality, for that matter) as Convention refugees, an examination of only such refugees would be slim indeed. Rather, this paper identifies Burmese refugees as those who claim to have fled Burma for political reasons. ${ }^{30}$

Until mid-2004, there were an estimated ten thousand Burmese living in Japan. Most began arriving following the military junta's brutal crackdown against democracy demonstrations in 1988, and others have continued to arrive ever since. Approximately 90 per cent of the ten thousand were illegal overstayers, individuals who came to Japan legally but remained past their legal allowance. The majority arrived with limited work or travel visas, and some arrived originally on student visas. A small number arrived by boat, former sailors in the Burmese military who deserted their ships and their crew. Others arrived through third countries such as Korea, the Philippines, or Thailand. A handful actually claimed refugee status when they arrived at the border (at airports near Tokyo or Osaka), but to my knowledge, none were accepted for refugee status immediately, although none were sent back outright.
In 2004, authorities from the MoJ threatened to reduce the number of overstayers by 50 per cent, and since then, employers have been fined for hiring illegal migrants, and arrests and detention have increased significantly. As a result, by mid-2005, the number of Burmese who remain in Japan is estimated to be between five thousand and seven thousand.

The approximately one thousand Burmese who reside legally in Japan who are not refugees are either government officials, businessmen who benefit from the current regime, or spouses of Japanese citizens, all of whom are reluctant to challenge the present military junta. While they may engage in transnational acts as migrants, they certainly could not be considered refugees under even the most liberal definition. This group of one thousand is, therefore, outside the scope of this paper's research.

The remaining Burmese overstayers in Japan are difficult to categorize according to motivation. While all are opposed to the ruling regime, their reasons for coming to Japan may be purely political or highly economic or anything in between. Like refugees everywhere fleeing a country in conflict, many Burmese fled to Japan to avoid the devastating impact of a failing economy, hoping to save their families not only from persecution, but from unemployment, malnutrition, and starvation. These aspirations are often ignored in Japan, as they are elsewhere. A sharp distinction between political and economic motivations does not reflect the reality of those fleeing a failing state. This study focuses on those who live on the political end of the spectrum, of whom approximately four hundred have received, applied for, or expressed intent to apply for refugee status.

\section{Legal and Residence Status in Japan}

Citizenship in Japan is notoriously difficult to obtain. ${ }^{31}$ Individuals of Korean descent whose parents and grandparents were born in Japan, who speak no other language but Japanese, have not been granted Japanese citizenship. There are few, if any, refugees of any nationality who are fully naturalized Japanese citizens. Additional categories inapplicable to refugees include individuals such as diplomats, artists, skilled labourers, spouses and children of citizens, and students. Notably, these categories, which confer permission to reside in Japan, are separate from legal status. The continuum below reveals both the legal categories and status of residence relevant to refugees:

$$
\text { Official refugee status } \leftrightarrow \text { special permission } \leftrightarrow \text { asylum seeker } \leftrightarrow \text { overstayer }
$$


Convention refugees, or those with official refugee status (nanming), are those recognized as such by the Japanese government. UNHCR's mandate status alone has certainly not been sufficient to protect refugees in Japan - early in 2005, two Kurdish asylum seekers with mandate status were refouled directly to Turkey, much to the shock of the advocacy community in Japan. While no Burmese with mandate status have been refouled, Japan's actions are not encouraging. Neither are UNHCR's. If mandate status was never entirely effective in protecting asylum seekers in Japan, it certainly no longer is; since the aforementioned deportation, UNHCR in Japan has chosen to stop giving mandate status to asylum seekers altogether.

While the total number of Burmese with official refugee status is small (approximately 80 from 1992 to 2004), it is still a significant percentage of the total nanming population in Japan, which numbered a total of 320 at the close of 2004. (As discussed earlier, Indochinese refugees were not given official refugee status and are therefore not included in this number.) In recent years, this pattern is even more prominent; in 2004, of the fifteen refugees recognized by the MoJ as nanming, fourteen were Burmese.

A greater number of Burmese have been able to secure temporary protection by being granted "special permission" (zaitoku) to stay in Japan, a category not unique to refugees, but applicable to all migrants. These Burmese refugees are also legal and they total approximately 130 . At the start of this research, I attempted to tease out differences between those with official refugee status and those with special permission, since they are legally distinct categories, but for all intents and purposes, their rights and lives are exactly the same. Both generally receive long-term residence status (teiju-sha) upon being granted legal recognition. I have, therefore, placed them in the same category for the purposes of comparison.

Asylum seekers (nanming nintei shinsei sha) deserve particular attention. They are pursuing refugee status, but have neither been accepted nor rejected yet. The great majority have no legal status when they apply - that is, they are overstayers, rather than, for example, students who apply for refugee status while they have legal rights to be in Japan. This category is important because (1) there are more Burmese asylum seekers than either those with refugee status or special permission (approximately 180 at the close of 2004); (2) their numbers are increasing daily; and (3) applying for status/asylum is a long process, generally lasting from one to three years. During this time, refugee participation in transnational activities is as important as before and after.

Given that most asylum seekers are illegal at the time of their application, they live precariously. Until recently, the very act of applying for asylum triggered their deportation procedure, which meant that, technically, they could be detained and deported while their cases were still under consideration. Recent revisions to the Immigration Control and Refugee Recognition Act, which went into effect on May 16, 2005, have somewhat improved their temporary security. Now, at the same time that asylum seekers submit their claims, they are automatically considered for a renewable provisional stay permit (karitaizai), which suspends deportation procedures until after a decision is made on their legal status. These changes and others in the law have come about due to the intense efforts of Japanese asylum lawyers, and, notably, in consultation with Japanese NGOs and even a Burmese individual with official refugee status. This is interesting evidence of transnational advocacy that improves conditions in the host country, rather than in the home country. ${ }^{32}$

By far the largest of number of Burmese fall into the category of overstayer (huko shurosha), but as noted earlier, there is no easy way to distinguish between those who have come only for economic reasons and those who have not. The number of those who would be identified as refugees under my definition may range anywhere from several hundred to several thousand.

From the above continuum, there are three categories into which refugees can be separated according to transnational activity. These categories provide the basis for comparison for the purposes of this paper:

$$
\begin{gathered}
\text { Illegal overstayer (category 1) } \\
\downarrow \\
\text { Asylum seeker (category 2) } \\
\downarrow
\end{gathered}
$$

Official refugee status or special permission (category 3 )

\section{Transnational Action for the Burmese in Japan}

While insignificant networks of scale may limit the transnational impact of the small and relatively new Burmese refugee community in Japan, transnational activities are still a critical element of life, particularly for those who have arrived recently. Almost all Burmese refugees whom I interviewed came to Japan with the assistance of migrants and/or refugees who preceded them, and most disclosed that they have helped others since arriving. Passports are falsified, apartments are shared, and the names of potential employers are circulated. Even before leaving Burma, information about legal procedure in Japan is available. The name of one prominent refugee lawyer in Tokyo is known in political circles in Burma's capital city, Rangoon, a clear indication that transnational circuits are functioning vigorously.

On the political front, transnational activities take common and expected forms. Refugees demonstrate in front of 
the Burmese embassy, distribute information about the military junta to local NGOs, lobby the government to end official development aid to Burma, write articles in English and Japanese newspapers, send money to the Thai-Burmese border, and organize and participate in Burmese cultural events. The picture of Burma's most famous dissident, 1991 Nobel Peace laureate Aung San Suu Kyi, can be found in many homes, on political circulars, and on the enormous posters that adorn political protests and cultural gatherings.

\section{Local Community Divisions}

Despite common ground in loathing the current regime and working for change, the refugee community is internally divided. Burmese refugees belong to a bewildering array of various political groups with every acronym imaginable, and deciphering the numerous personal vendettas and political issues that surround the formation of each group would be akin to untangling a scouring pad into a line of thread. Political demonstrations in Tokyo and cultural events in various locations present a relatively united face to Burma's military junta, and this image of cohesion is, of course, critical. However, when signs come down and ethnic costumes come off, griping is common.

Some refugees insist that it is impossible to obtain legal status unless you are a member of a particular political group. Others counter that increasingly restrictive policies on the part of the Japanese government have led some Burmese to abuse the asylum system. Some Burmese ethnic minorities point out that they are excluded from the most prominent refugee political groups. Others respond that hard-line ethnic minority goals (which few espouse, at least openly) are incompatible with the democracy struggle. These examples highlight how much tension is generated in the community by discussions about who "deserves" refugee status.

In Japan and elsewhere, divisions between Burma's majority population and its ethnic minorities are profound. The majority Burmans desire democratic rule while the ethnic minorities want various degrees of autonomy and independence. There lies deep distrust among the groups. Silverstein traces a longstanding divide-and-rule strategy that feeds and is fed by a pattern of ethnic rivalry, while Rajah demonstrates that conflicting interests among the ethnic groups make such methods successful for the current regime as well. ${ }^{33}$ Today, both the lack of open communication and the varying demands of Burma's many ethnic groups - from democracy to autonomy to independence complicate the processes of future reconciliation. ${ }^{34}$ It is a sobering reality that even if Burma's military junta were to cede power tomorrow, reconciliation is not by any means assured. This is why positive transnational links are critical.
In Japan specifically, there are divisions between the Burmans and the ethnic minorities (of whom there are ten groups in Japan: Chin, Kachin, Karen, Lahu, Paluang, Rakhine, Shan, Mon, Naga, and Rohingya). The ethnic minority groups believe that their low numbers of legal status (with the exception of the Rohingya, discussed below) are due to the fact that Burmans have been unwilling to allow the ethnic minorities into leadership in political organizations in Japan. Because they are not represented in political groups, the minorities believe, they cannot prove refugee status. Japanese lawyers have asserted that political leadership positions are not necessary to obtain legal status, but the perception remains. On their part, many Burmans believe that ethnic minorities have not protested loudly enough to qualify as refugees.

Even among the ethnic minorities, the Muslim Rohingyas are patently excluded from community events, channels of information, job opportunities, and help with housing. The Rohingya, who number approximately seventy in Japan, have an unusually high rate of legal recognition (approximately twenty have been accorded refugee status or special permission, category 3 ), due to their significant ability to prove fear of persecution in Burma. In essence, the Rohingya provide support within their own group, and legal status reinforces, rather than weakens, their very small community. However, the provision of legal status tends to increase hostility against the Rohingya as a group (which divides the ethnic minorities further). The ability of the Rohingya to function transnationally requires further study.

Clearly, personal rivalries and ethnicity play a noteworthy role in creating rifts among refugees in Japan, but more relevant and increasingly evident because of restrictive government policies, the application and provision of legal status damages local community cohesion. Rather than working toward a common goal, refugees now compete with one another for the scarce resource of legal recognition. This finding is critical to part of my thesis, which is that legal recognition does not always expand transnational space.

Transnationalism clearly plays a role in facilitating information that supports daily efforts: one man explained to me the following chain that brought him to a Japanese language program: the political group of which he was a member in Burma recommended the name of a lawyer in Tokyo, who sent him to UNHCR. UNHCR referred him to a Japanese refugee NGO, which informed him about the Japanese agency that provides language programs. This refugee's original contact source, from which he received the information that allowed him to access other resources, exemplifies transnationalism at work. 
In theory, refugees in category 1, the overstayers, have the least freedom to move about and protest in public. We would thus expect that their involvement in political transnationalism would be minimal, while we would expect that those refugees in category 3 with legal allowance to reside in Japan would be the most vocal and active. Given the finding by Shah that asylum seekers have been rejected for political agitation, we would expect category 2 asylum seekers to keep out of the public sphere as well. ${ }^{35}$ Because of refugees' interactions with their local communities, the reality in Japan is far different.

\section{Overstayers (Category 1)}

Overstayers in category 1 present a complicated picture because of the aforementioned difficulty in teasing out motivation. The majority of overstayers are not involved politically whatsoever, focusing only on their livelihoods, but this group does not fall into the refugee category. There are many overstayers, however, who are politically active. They have chosen to remain illegal for a number of reasons. Many have families in Burma whom they fear would be harmed if they applied for refugee status. Others eschew the taboo label "refugee." This subgroup of overstayers, whom I call category 1, whose members are illegal but involved politically, do involve themselves in some transnational activities, such as attending political meetings and cultural events, sending money home, and providing contacts, information, and assistance to new arrivals. Until recently, they also attended demonstrations and marches, but a sobering account (circulated transnationally), which occurred in 2004, has impeded this activity: an overstayer who often protested at the Burmese embassy was arrested and deported back to Burma, whereupon he was detained straight from the airport. ${ }^{36}$ Importantly, because they have not claimed refugee status, these individuals retain their Burmese passports. Therefore, they are a key mechanism for bringing money, documents, and packages to and from Burma. ${ }^{37}$ Transnational networks ensure that local communities in both countries know where, when, and how to find these one-time transpostal deliverymen.

A curious phenomenon is worth noting. Many overstayers from Burma admitted coming to Japan primarily for economic reasons. Upon arrival, they heard from the vocal local community what they never learned in Burma. Stories of forced labour, rape, arrest without due process, and countless egregious actions by the Burmese military awakened their sense of conscience. While never interested in protesting in Burma, these overstayers became more political than they ever would have been at home. ${ }^{38}$ Political transnational space is thus magnified by the presence of a local community of overstayers, and as the migrant community continues to grow, so may the number of activists.

\section{Legal Refugees (Category 3)}

Category 3 refugees are more comfortable in public spaces, and thus they are able to practice the permeating Burmese culture of meeting at tea houses to gossip and discuss sports and politics. Some are active on the advocacy scene. The majority, however, are absent from political demonstrations and minimally involved in efforts toward political transformation in Burma. They may engage in transnational acts such as bringing family members from Burma to live with them in Japan, but their participation in political transnational events is low. ${ }^{39}$

Why have many category 3 refugees removed themselves from the political and transnational arenas? First, legal status has furnished them with the potential to lead a more normal life - to live with their family members, to secure long-term jobs, to receive health care, and to take vacations. After years of living in fear, many legal refugees have refocused their energies on livelihood, rather than political, activities.

Second, many category 3 refugees in Japan have curtailed their political activities because they feel unwelcome in the local communities where they were accustomed to spending time. Jealousy appears to play a role, and resentment is present as well. Once they have received legal status, category 3 refugees are viewed as traitors to the cause. Purist democracy activists assert that legal recognition corrupts the political movement, because Japanese officials can then claim that obtaining refugee status is only a strategy to remain in the country, rather than a critical way to protest the ruling regime. Legal status, then, is perceived of as a rejection of political transnationalism. Because so much political advocacy takes place in local communities, this dynamic plays a significant role in reducing the transnational actions of legal refugees. ${ }^{40}$

\section{Asylum Seekers (Category 2)}

Despite the fact that they are in danger of being picked up by police, category 2 asylum seekers are the most active politically, attending demonstrations and protesting at the Burmese embassy almost daily (if they are not in detention, in which case their spouses are likely to be involved in protests). This is so for two reasons. First, asylum seekers believe that their cases will be substantiated more easily if they can prove political involvement in Japan, lawyers' assurances to the contrary notwithstanding. The misperception that transnational political action enhances the likelihood of legal recognition is widespread in the Burmese refugee community and clearly complicates refugees' decisions about political activism.

Second, those who choose to seek asylum are often at greater risk for being arrested. Some have had, or fear, a run-in with the police. Others try to obtain refugee status 
immediately upon arriving in Japan. Either way, they are the most apprehensive about their current circumstances, and require the most support from their local community. Because community connections are reliant on putting in "face time" at demonstrations and local political meetings, category 2 refugees not only attend gatherings of all kinds, but help with the tedium involved in running them. Ever in danger of being caught by the police and less likely to be securely placed in a long-term job, it is the category 2 refugees, not the majority of illegal overstayers, who are the most vulnerable in Japan. They are the most intermediate of an already intermediate-term population.

The intricacies of the Burmese refugee community are not unique to Japan, but the divisions created by the provision of preciously guarded legal status aggravate the three-way relationship already described. While many assume that legal status improves the ability of refugees to engage in political and social transformation, the provision of legal status can have the opposite effect, weakening fragile community structures, stemming advocacy efforts, and discouraging communication between divided political and ethnic groups. Thus, transnationalism, rather than acting as a simple function of legal status (Figure 1), is more likely to be defined by the interactions described in Figure 2.

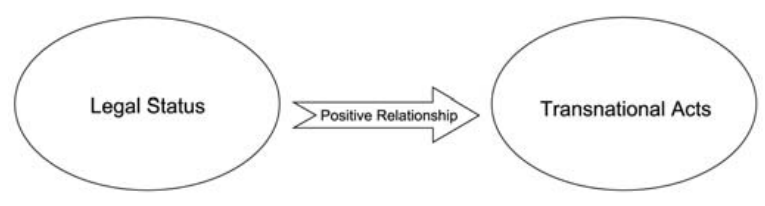

Figure 1. Unidirectional Relationship

\section{Conclusion}

The crafting of new democracies often demands patience and reconciliation, rather than revenge or an arbitrary 'settling of accounts.' It also requires courageous leadership on the part of both outgoing authoritarian regimes and their democratic opposition, and a broad understanding among supporters of democracy that not everything can be achieved quickly. Diasporic forces that push for immediate results at the expense of long-term political healing and viability may therefore compromise or endanger the political 'progress' they seek to encourage. This is particularly pertinent to the case of exiles whose personal experiences of war and injustice prior to their departure, and their commitment to continue the struggle while abroad, have left them frozen in time. ${ }^{41}$

While Burma's refugee population has the ability and potential to engage in helpful and positive transnational action, communication and co-operation on the local com-

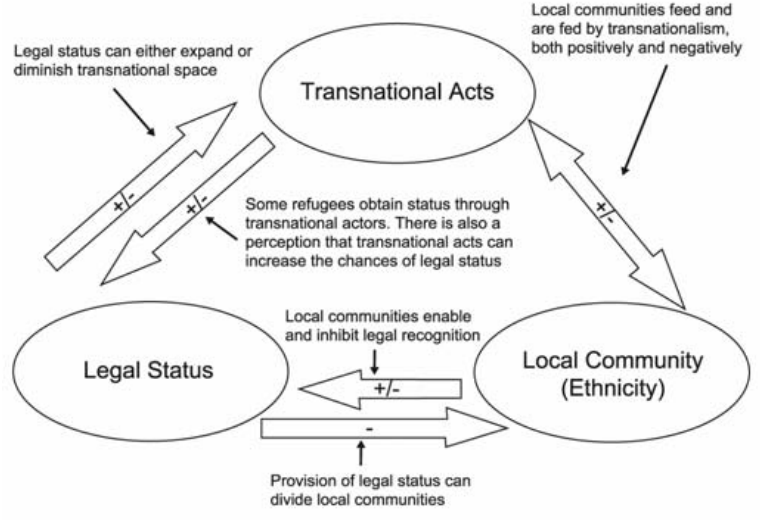

Figure 2. The Triadic Relationship

munity level are critical. In this paper, I have suggested that transnational potential - both positive and negative - stems from both legal status and local community dynamics. In attempting to generate new spaces (ideas and possibilities for regime change) in old places (the home country), an understanding of this three-way relationship will, it is hoped, contribute to the discussion on transnationalism. Legal recognition does provide important benefits to refugee populations, but a better understanding of its divisive effects on refugee communities will help the international refugee regime to focus on the gaps that remain in its wake.

\section{Notes}

1. Osten Wahlbeck, "The concept of diaspora as an analytical tool in the study of refugee communities," Journal of Ethnic and Migration Studies 28 (2002): 223.

2. A lengthier discussion of transnationalism follows, but transnational space refers to the arena where transnational life takes place. It is the space where, for instance, foreign workers transfer funds overseas, where migrants raise and resolve tensions among family members caught between the traditional culture of their home country and the modern culture of their host country, and where refugees struggle to balance the realities of their current lives with their desire to return to their homeland. Faist has elaborated on the term "transnational social spaces" and offered preconditions under which transnationlism occurs. Thomas Faist, The Volume and Dynamics of International Migration and Transnational Social Spaces (Oxford: Clarendon Press, 2000), 198.

3. See, for example, John Baylis and Steve Smith, eds., The Globalization of World Politic, (New York: Oxford University Press, 1997), 526

4. In this paper, the definition of "refugee" includes both those with and those without official refugee status, since the very 
purpose of the paper is to compare varying groups. As discussed further on, Burmese "refugees" are identified in a broader scope than what would be dictated by official designation.

5. Wahlbeck provides an extensive review of the distinctions between transnational groups and diasporas, and presents a neat summary of the different academic approaches to diaspora. Additionally, he advises against spending too much time trying to determine whether or not a particular group actually constitutes a diaspora (Wahlbeck, 228-32). I will heed his warning and stay away from the subject altogether.

6. While the physical movement of individuals is easier today, border restrictions have limited migration politically. Transnational efforts to mitigate or circumvent quotas, visa requirements, or detention are just some aspects of transnationalism's increasing significance.

7. Several authors have explored refugee involvement in political advocacy. See, for example, Gisele Bousquet, Behind the Bamboo Hedge: The Impact of Homeland Politics in the Parisian Vietnamese Community (Ann Arbor: University of Michigan Press, 1991) and Oivind Fuglerud, Life on the Outside: The Tamil Diaspora and Long-Distance Nationalism (London: Pluto Press, 1999).

8. Fiona Adamson, "Mobilizing for the Transformation of Home: Politicized Identities and Transnational Practices," in New Approaches to Migration? Transnational Communities and the Transformation of Home, ed. Nadje Al-Ali and Khalid Koser (London: Routledge, 2002), 155-68.

9. Nicholas Van Hear, "From Durable Solutions to Transnational Relations: Home and Exile among Refugee Diasporas" (Working Paper No. 83, New Issues in Refugee Research, UNHCR, Geneva, 2003), 3.

10. Koser and Al-Ali examine the meaning of home in Nadje Al-Ali and Khalid Koser, "Transnationalism, International Migration, and Home," in New Approaches to Migration? Transnational Communities and the Transformation of Home, ed. Nadje Al-Ali and Khalid Koser (New York: Routledge, 2002), 1-14.

11. Ibid., 5.

12. Van Hear, 3.

13. Ibid., 15.

14. See Susan Banki, "Refugee Integration in the Intermediate Term: A Study of Nepal, Pakistan, and Kenya" (Working Paper No. 108, New Issues in Refugee Research, UNHCR, Geneva, 2004), 4.

15. Stephen Castles and Nicholas Van Hear, "The Migration-Asylum Nexus: Definitions and Dimensions" (paper presented at the 9th International Association for the Study of the Forced Migration Conference, São Paulo, 9-13 January 2005).

16. For example, see Mohamed Kamel Dorai, "Palestinian Emigration from Lebanon to Northern Europe: Refugees, Networks, and Transnational Practices," Refuge 21 (2003): 23-31; Dorai notes that transnational links remain weak until individuals receive legal status. Faist specifically points to the host government's juridical and political regulations as a factor which permits refugees to travel and protest freely (2000).

17. I have argued elsewhere that legal recognition does not necessarily offer all of the freedoms that improve refugee quality of life that we assume it will, but this point steps away from questions about transnational action. See Susan Banki, "Community and Quality of Life: The Consequences of Legal Status for the Burmese Refugees in Japan" (paper presented at the 9th International Association for the Study of the Forced Migration Conference, São Paulo, 9-13 January 2005).

18. Val Colic-Peisker, "Bosnian Refugees in Australia: Identity, Community and Labour Market Integration" (Working Paper No. 97, New Issues in Refugee Research, UNHCR, Geneva, 2003), 7.

19. Prakash Shah, "Taking the 'Political' Out of Asylum: The Legal Containment of Refugees' Political Activism," in Refugee Rights and Realities: Evolving International Concepts and Regimes, ed. Frances Nicholson and Patrick M. Twomey (Cambridge: Cambridge University Press, 1999), 119-35.

20. Dorai, 23-31.

21. Jeff Crisp, "Policy Challenges of the New Diasporas: Migrant Networks and Their Impact on Asylum Flows and Regimes" (Working Paper No. 7, New Issues in Refugee Research, UNHCR, Geneva, 1999), 6.

22. Guido Ambroso, "Pastoral Society and Transnational Refugees: Population Movements in Somaliland and Eastern Ethiopia 1988-2000" (Working Paper No. 65, New Issues in Refugee Research, UNHCR, Geneva, 2002).

23. Mulki Al-Sharmani, "Refugee Livelihoods: Livelihood and Diasporic Identity Constructions of Somali Refugees in Cairo" (Working Paper No. 104, New Issues in Refugee Research, UNHCR, Geneva, 2004).

24. For an in-depth discussion of the intermediate term, see Banki 2004, 5 .

25. In 2003, Japan donated $\$ 100.5$ million to UNHCR, IOM, and UNRWA, a contribution greater than any other single country other than the US. However, its refugee acceptance rate was extremely low. Its ratio of refugee population to total population was 1:16,139, compared to the US at 1:1,194 and Thailand at 1:150. See USCR, World Refugee Survey 2003 (Washington, DC: USCR, 2004), 14-15.

26. Ryuji Mukae, Japan's Refugee Policy: To Be of the World (New York: U.S. Committee for Refugees, 2002).

27. Koichi Koizumi, "Resettlement of Indochinese Refugees in Japan (1975-1985). An Analysis and Model for Future Services," Journal of Refugee Studies 4 (1991): 182-99.

28. Isami Takeda, "Japan's Responses to Refugees and Political Asylum Seekers," in Temporary Workers or Future Citizens? Japanese and U.S. Migration Policies, ed. Myron Weiner and Tadashi Hanami (New York: New York University Press, 1998), 431-51.

29. Myron Weiner, "Opposing Visions: Migration and Citizenship Policies in Japan and the United States," in Temporary Workers or Future Citizens? Japanese and U.S. Migration Poli- 
cies, ed. Myron Weiner and Tadashi Hanami (New York: New York University Press, 1998), 23.

30. The effort to distinguish between Burmese who fled to Japan for political rather than economic reasons highlights the issue of the aforementioned "migration/asylum nexus," which might be better called a "continuum" in this context. This paper is interested in the effect of legal labelling, rather than in identifying individuals as "real" refugees (a misled effort to be sure). Therefore, I did not track down spurious claims or specific facts that would challenge/substantiate refugee status, but rather focused on how that status (or lack) shaped transnational space. As discussed in the next section, these refugees lie somewhere on the legal spectrum from Convention refugees to totally illegal.

31. For much of the information in the following section, I am indebted to Eri Ishikawa, Senior Legal Researcher at the Japan Association for Refugees; see http://refugee.or.jp.

32. The revisions to the law are not perfect by any means. Two major criticisms have been leveled thus far: (1) asylum seekers are not permitted to work, which is an unreasonable expectation for individuals who generally lack resources; (2) the revisions in the law created an independent body of Adjudication Counselors to review appeals, but the hearings are limited to an hour, even if translation is necessary. As a result, several asylum lawyers are boycotting these hearings.

33. Josef Silverstein, "The Evolution and Salience of Burma's National Culture," in Burma: Prospects for a Democratic Future, ed. Robert Rotberg (Washington, DC: Brookings Institution Press, 1998), 11-32; and Ananda Rajah, "Ethnicity and Civil War in Burma: Where Is the Rationality?" in Burma: Prospects for a Democratic Future, ed. Robert Rotberg (Washington, DC: Brookings Institution Press, 1998), 135-52.

34. This is part of a much larger problem in Burma's future, which deserves closer treatment in another format.

35. Shah, 126.

36. Confidential interview with Burmese refugee in Japan, August 2005.

37. There are only so many times that overstayers can return to Japan once they leave, but new arrivals with legal permission to work (who have not yet become overstayers) replace those who leave permanently.

38. While my relationship with an extremely reputable and trusted law firm probably helped create trust with those I interviewed, I acknowledge that refugees are likely to tell a story that highlights their activities as pro-democracy demonstrators and minimizes their images as illegal migrants. It is possible that some refugees told me of their "political awakening" in this vein, but I heard the story not only from overstayers and asylum seekers, but from those who were entirely secure in their legal status.

39. Note that some refugees reject legal status for fear of harming their families in Burma, while others obtain legal status in order to send for them. This contradiction requires further study.
40. Two related factors may change this relationship. First, if the Japanese government's crackdown on illegal migrants forces increasing numbers of them to claim refugee status, the marginalization of those who apply will lessen. Second, as more refugees receive legal status, the legal local refugee community will grow in size and perhaps in political strength. From my observations during a follow-up visit in August 2005, both of these phenomena are starting to occur.

41. Yossi Shain, Marketing the American Creed Abroad: Diasporas in US and Their Homelands (Cambridge: Cambridge University Press, 1999), 83.

Susan Banki is a Ph.D. candidate at the Fletcher School of Law and Diplomacy at Tufts University in Medford, Massachusetts. She has worked with Burmese refugee communities in Thailand and Japan.

The research for this paper was made possible by a generous grant from the Tokyo Foundation. Profound thanks are due to Shogo Watanabe and the employees at Izumibashi Law Office in Tokyo, Japan, for their continual assistance to me and more importantly to Japan's refugee population. 